\title{
SOME DISCOURSE-BASED SUGGESTIONS THAT BOOST CRITICAL THINKING SKILLS IN ELT CLASSES
}

\begin{abstract}
Nuray Alagözlü
Abstract

Recent approaches in education aim at cognitive processes, defined in terms of learner autonomy principles. Learners should be taught how to think rather than what to think. Judging, reasoning, problem solving, decision making are vital for successful academic and social lives (Collier, et al., 2002:7). Critical thinking is the ability to judge an idea/claim based on reliable evidence by determining one's own criteria (Beyer, 1995). Especially, in a rote-memorization based educational system as in Turkey, learners need to be taught to express their own thoughts and to judge the ideas before making a decision and solving the problems. In this paper, some classroom applications to improve critical reading in ELT will be presented.
\end{abstract}

Key words: Critical Thinking Skills, English Language Teaching, Reading

\section{DIL ÖĞRETIMINDE ELEŞTİREL DÜŞÜNME BECERILERINI GELISTTIREBILECEK SÖYLEM ODAKLI BİR KAÇ ÖNERİ}

\begin{abstract}
$\ddot{O}_{z e t}$
Öğretimde yeni yaklaşımlar, bireysel planlama ve sorumluluk alma ilkelerine gore tanımlanan düşünme süreçlerini hedefler. Öğrenciye ne düşüneceğini değil nasıl düşüneceğini ögretmeyi esas alır (Taylor, 2001). Yargılama, sebebe dayandırma, problem çözme, ve karara varma ögrencinin okulda ve hayatta başarılı olmaları için hayati önem taşıyan becerilerdir. (Collier ve ark.,2002:7). Eleştirel düşünce bireyin kendi ölçütlerini belirleyip doğru güvenilir bir kanita dayan-dırarak bir iddiayl veya bir düsünceyi sorgulama yeteneğidir (Beyer, 1995). Özellikle ezbere dayall eğitim veren Türk Eğitim Sistemi'nde ögrencilere kendilerini ifade edebilmeleri, problem çözme ve karara varmadan önce sunulan düşünceleri yargılayabilme becerileri ögretilmelidir. Bu makalede, ögrencilerin eleştirel okumalarını gelişstirmek için İngilizce Öğretimi'nde kullanılabilecek birkaç sını içi uygulama sunulacaktır.
\end{abstract}

Anahtar sözcü̈kler: Eleştirel Düşünme Becerileri, İngilizce Öğretimi, Okuma 


\section{1- Introduction}

The results of PIRLS (Progress in International Reading Literacy Study) research in 2004, which evaluated four reading comprehension strategies among 150000 children of 9 and 10 in European Union and candidate countries, in relation to their social environment, in terms of a)Focus on and retrieve explicitly stated information, b) Make straight forward inferences, c) Interpret and integrate ideas and information, d) Examine and evaluate content, language, and textual elements (http://timms.bc.edu/pirls2001) showed that Turkish students along with Cyprus, Slovenia, and Norway appear to be towards the end of the scale. This situation might be open to any interpretation. Frankly speaking, for years, it has been informally observed that Turkish students are involved in a rote memorization-based instruction and are required to receive any information without any questioning (whether it be oral or be in a text), and therefore they are unable to use the knowledge in their daily lives. Moreover, their attempt to question or comment on what is taught and read is in vain as such an attitude is not acceptable in the traditional instructional process during which the learners are not encouraged to think effectively and critically.

This might indicate a deficit in the instruction of thinking strategies, which is also transfered to ELT reading classes in Turkey. Teaching the learners how to think critically seems to help repair the deficiency indicated and might make them get aware that they are important as individuals and their ideas/thoughts, decisions, evaluations are of great value in their education both in the mother tongue and in a foreign language. Involving thinking strategies in teaching process will absolutely contribute to teaching and learning any issue including language teaching in terms of the quality and the amount of learning, and the persistence of knowledge or lifelong knowledge. Although we are all engaged in thinking in our daily lives, the type of thinking intended is a learned and planned process which requires a step by step elaboration and practice.

In this paper, having focused on the importance of teaching critical thinking skills to language learners in teaching reading in ELT, some classroom applications will be presented.

\section{2- Critical thinking}

Although there are some quite diverse definitions of critical thinking, nearly all emphasize the ability and tendency to gather, evaluate, and use information effectively (Beyer, 1985). Chance (1986:6) defines critical thinking as the ability to analyze facts, generate and organize ideas, defend opinions, make comparisons, draw inferences, evaluate arguments and solve problems. 
Critical thinking skills aim at teaching the learner how to think rather than what to think (Taylor, 2001). In critical thinking, collecting, elaborating and using data are crucial. The components of critical thinking which are reasoning, problem solving, decision-making along with creative thinking are thought to be the skills of vital importance for success at school and in life (Collier, et al., 2002:7).

Perhaps, the simplest definition is offered by Beyer (1995:8) "Critical thinking... means making reasoned judgments". Basically, Beyer sees critical thinking as using criteria to judge the quality of something, from cooking to a conclusion of a research paper. In essence, critical thinking is a disciplined manner of thought that a person uses to assess the validity of something (statements, news stories, arguments, research, etc.) (Beyer 1995)

Beyer (1995) proposes a metacognitive model in which he classifies thinking subskills. Beyer's taxonomy of thinking skills proposes one to think, solve the problem and reach a decision. To achieve all these, the individual should make use of any subskills which lead to a process during which s/she conceptualize, decide and validate the most appropriate solution for the identified problem. Beyer (1995) suggests that human beings exercise three levels of cognitive activity (thinking) in which the individuals are engaged to solve problems and make decisions making.

At Level III, the foundational level is composed of eight microthinking skills. At level II, we use an array of microthinking skills to produce at least ten criticalthinking operations. At Level I, we use microthinking skills and critical thinking operations in three strategic ways: conceptualizing, decision making, and problem solving.

Each level can be taken as a robust basis for a questioning that will trigger thinking and a teacher might address these levels of thinking in the classroom, though this is not an easy job and requires elaborated study and contemplation over it.

First, Beyer (1995) identifies eight foundational thinking skills. They are as follows:

\section{Level III Microthinking Skills}

1. recall - to remember facts and bits of information

2. translation - to put into simpler or different terms

3. interpretation - to explain

4.extrapolation - to infer or estimate by extending / projecting known information

5. application - to use known information in new settings / situations

6. analysis - to separate a concept / idea / entity

7. synthesis - to combine elements into a coherent concept / idea / entity

8. evaluation - to judge, to determine the goodness / badness, rightness / wrongness, appropriateness / inappropriateness of a situation, concept, idea, etc. 


\section{Level II Critical thinking Operations}

Beyer identifies 10 critical thinking operations:

1. distinguishing facts from value claims

2. distinguishing relevant from irrelevant information

3. determining factual accuracy of a statement

4. determining credibility of a source of information

5. identifying ambiguous claims or arguments

6. identifying unstated assumptions

7. detecting bias

8. identifying logical fallacies

9. recognizing logical inconsistencies in a line of reasoning

10. determining the strength of an argument or claim

\section{Level I -Thinking Strategies}

At Level I of his model, Beyer identifies three broad thinking strategies, each characterized by a series of mental steps requiring the use of microthinking skills and critical-thinking operations. Below are the three strategies with the steps pertaining to each:

\section{Conceptualizing}

1. identify examples of practice, behavior

2. identify common attributes of the examples

3. classify the attributes

4. interrelate categories of attributes (build a concept)

5. identify additional examples and nonexamples (to see whether the oncept fits/works)

6. modify the concept (and attributes) if necessary

\section{Decision making}

1. define goals

2. identify alternative approaches

3. analyze each alternative (pros and cons)

4. rank alternatives

5. determine the highest ranked alternative(s) (Why are they highest ranked?)

6. choose the "best" alternative 

Problem-solving
1. recognize the problem
2. represent/describe the problem
3. devise or choose a plan for solution
4. execute the plan
5. evaluate the results

To sum up, critical thinking involves identifying, evaluating, and constructing arguments and the ability to infer a conclusion from one or multiple premises. To do so requires examining logical relationships among statements or data. Ambiguity and doubt serve a critical-thinking function and are a necessary and productive part of the process, urging one to continue their search until they reach the correct conclusion.

Critical thinking is the ability to determine one's own criteria and to judge and question an idea or thought based on reliable evidence and produce assertions. An assertion must... "be based on relevant, accurate facts; based on credible sources; precise; unbiased; free from logical fallacies; logically consistent; and strongly reasoned" (Beyer, 1995).

Critical thinking involves:

- Asking questions

- Defining a problem

- Examining evidence

- Analyzing assumptions and biases

- Avoiding emotional reasoning

- Avoiding oversimplification

- Considering other interpretations

- Tolerating ambiguity (Uzma, 2005).

Critical thinkers are skeptical and open-minded, they value fair-mindedness, respect evidence and reasoning, respect clarity and precision. They look at different points of view, and will change positions when reason leads them to do so (Uzma, 2003).

\section{3- Teaching Reading and Critical Thinking (Critical Reading)}

Kurland (2000) states that to non -critical readers, texts provide facts. Readers gain knowledge by memorizing the statements within a text. To the critical reader, any single text provides but one portrayal of the facts, one individual's "take" on 
the subject matter. Critical readers thus recognize not only what a text says, but also how that text portrays the subject matter. They recognize the various ways in which each and every text is the unique creation of a unique author.

A non-critical reader might read a history book to learn the facts of the situation or to discover an accepted interpretation of those events. A critical reader might read the same work to appreciate how a particular perspective on the events and a particular selection of facts can lead to particular understanding.

Knott (2005) proposes five steps to read looking for ways of thinking:

1. First determine the central claims or purpose of the text (its thesis). A critical reading attempts to assess how these central claims are developed or argued.

2. Begin to make some judgements about context . What audience is the text written for? Who is it in dialogue with? (This will probably be other scholars or authors with differing viewpoints.) In what historical context is it written? All these matters of context can contribute to your assessment of what is going on in a text.

3. Distinguish the kinds of reasoning the text employs. What concepts are defined and used? Does the text appeal to a theory or theories? Is any specific methodology laid out? If there is an appeal to a particular concept, theory, or method, how is that concept, theory, or method then used to organize and interpret the data? You might also examine how the text is organized: how has the author analyzed (broken down) the material? Be aware that different disciplines (i.e. history, sociology, philosophy, biology) will have different ways of arguing.

4. Examine the evidence (the supporting facts, examples, etc) the text employs. Supporting evidence is indispensable to an argument. Having worked through Steps 1-3, you are now in a position to grasp how the evidence is used to develop the argument and its controlling claims and concepts. Steps 1-3 allow you to see evidence in its context. Consider the kinds of evidence that are used. What counts as evidence in this argument? Is the evidence statistical? literary? historical? etc. From what sources is the evidence taken? Are these sources primary or secondary?

5. Critical reading may involve evaluation. Your reading of a text is already critical if it accounts for and makes a series of judgments about how a text is argued. However, some essays may also require you to assess the strengths and weaknesses of an argument. If the argument is strong, why? Could it be better or differently supported? Are there gaps, leaps, or inconsistencies in the argument? Is the method of analysis problematic? Could the evidence be interpreted differently? Are the conclusions warranted by the evidence presented? What are the unargued assumptions? Are they problematic? What might an opposing argument be? 
Then, in reading critically the following aspects of the text content should be considered. 1-arguments (the claims supported by reasons (Stapleton, 2001:516)). 2- In what way reasoning is used to support the arguments? 3- From which perspective the writer handles the issue? 4- What evidence is used to support the claims?

Teaching critical thinking skills means guiding the students through judging and questioning an idea or thought based on a reliable evidence by establishing logical relationships among the statements or data. Therefore in reading, we, teachers, should expect the learners to perceive and recognize

1. claims

2. the claims with reasons (arguments)

3. evidence

4. opposing arguments

5. refutations (to correspond them)

6. fallacies (flawed reasoning) (Stapleton, 2001)

Unless the students are guided to recognize the above aspects in a text, they will suffer from the inability to question and judge the presented knowledge in the text and will not identify the conflicts/the problems in it and they all agree with whatever the text says and internalize what is readily given and will get by with the thoughts of somebody else, without thinking and without trying to find possible solutions for the problems/conflicts he identified. They will, perhaps, avoid a personal discovery.

Although critical thinking appears to be quite philosophical and sophisticated, in its centre lies the question "why" (Taylor, 2003:10). Though the central question seems to be "why", all sorts of questioning are needed. Learners should learn to explore the phenomena behind what is apparent by questioning. At this point a disciplined and carefully structured questioning is needed possibly to address to Beyer's levels of thinking. For example, a Socratic approach to teaching may be prefered to help students list and examine support, reasons, evidence, and assumptions related to the central statement which help critical thinking. A Socratic approach to teaching is the one in which the instructor poses thoughtful questions and is based on the practice of disciplined, rigorously thoughtful dialogue (Paul, 1990) (see Appendix 1). 


\section{4- Some Classroom Applications to Improve Critical Thinking Skills in Reading}

It is possible for a reader to answer the questions related to a text without thinking much. If we consider the following statement, the questions can be easily answered with little effort.

\begin{tabular}{|l|l|}
\hline \multicolumn{2}{|l|}{ The Griney grollers grangled in the granchy gak? } \\
\hline Questions & Answers \\
\hline Where are they? & in the granchy gak \\
\hline Who grangled in the granchy gak? & The Griney grollers \\
\hline Where did the Griney grollers grangle? & in the granchy gak \\
\hline What did the Griney grollers do? & They grangled \\
\hline What sort of Grollers grangled in the granchy gak? & Griney \\
\hline In what sort of gak did the griney grollers grangle? & granchy \\
\hline
\end{tabular}

(Taken from Russel, 1996:2)

The moral to be taken out of this is that students can answer low-level questions without thinking. What, then, should be done to include critical thinking into reading classes? In line with Beyer (1995) clarification, critical thinking is a disciplined manner of thought a person uses to assess the validity of something, ie: statements, news, stories, arguments, research, etc. (Beyer 1995), therefore, the following can be suggested for classroom use.

1) Statements: Occam's Razor: By supplying the simplest explanation for a phenomenon (Occam's Razor), students might be encouraged to produce multiple explanations after a reasonable time to think is given. Occam's razor is a principle attributed to the 14th century English logician, William Occam that forms the basis of methodological reductionism, also called the principle of parsimony or law of economy(Wickipedia, 2005). Simply, the simplest version is preferred when multiple explanations are available for a phenomenon. For example, there might be many possible explanations for the following statements:

\section{Occam's razor}

1. While grading a test, a teacher noticed that two students who are not doing well in class and sit next to each other answered a paragraph long question identically and incorrectly. (http://physics.csustan.edu/Ana/occams.htm)

2. There is a table with empty dishes in the middle of the room.

3. A baby is screaming.

4. People are rushing in a hurry. A bright flying object is approaching

5. A man is carrying a big parcel in his hands.

(adapted from Oral, 2005) 
1- a) the students copied each other,

b) the students made up an answer and somehow both brains came up with the exact same words.

2- The household will have a dinner or they have just finished doing that.

3- S/he is hungry or she needs a diaper.

4- They are scared of the object approching

5- He probably bought a present for someone.

2) Scenarios: Scenarios can be used to trigger and enhance critical thinking. They can be constructed by either the teacher or by the students. Real life situations can be used as well. In handling with the scenarios, each student might come up with different ideas (fallacies) and discuss. They might reach a decision or find solutions cooperatively. Scenarios enable the students to develop their problem solving abilities. The aim is to direct the students to produce ideas as many as possible and to have them make judgments and reach a conclusion from multiple premises based on evidence in the scenarios and establishing logical relationships among the statements or data.

Scenarios might be taken from news media. Newspapers, magazines, television, and radio can motivate students to develop critical listening and reading skills. Differing accounts and editorials can be compared as a way of helping students read with a questioning attitude. Students can construct their own arguments for discussion or publication in student newspapers. In the process, they become more discriminating consumers of news media, advertising, and entertainment (Carr, 1990).

\section{SCENARIO 1-}

\section{THE LACI PETERSON CASE (from CBS News)}

It was Christmas Eve, 2002. Laci Peterson left her home and was not seen again. Eight months pregnant and in the company of the family dog, it seemed she had simply vanished.

Secretly recorded audiotapes of phone conversations between Scott Peterson, her husband, and his mistress were played at Peterson's trial. Gloria Gomez reports on the continuing testimony of Amber Frey. There are audiotapes of Amber Frey getting Scott Peterson to talk about their future together. Amber Frey talks to Scott Peterson to talk about why he's attracted to her and what she deserves.

Scott Peterson's former mistress Amber Frey was once again the center of attention at Peterson's murder trial - both in person and on tape. Brian Andrews reports. 
The bodies of Laci Peterson and her unborn baby boy washed ashore last week about three miles from where Scott Peterson said he was fishing in San Francisco Bay when his wife vanished.

Scott Peterson's mother and his father have both said they are sure their son is not guilty. "It's something I didn't want to see happen, I didn't anticipate," said Lee Peterson of his son's arrest. "He could not do anything bad," said Peterson, commenting in an exclusive interview on the CBS News Early Show. "He and Laci were so much in love. I mean, they had just a wonderful relationship. They were just so happy and anticipating the baby."

\section{SCENARIO 2 -The Case of the Murdered Principal}

Cowtown Gazzette

Dateline Cowtown, Semptember 25

The body of Principle Stern was discovered today near the duck pond in Tulip Park last night. It appears that he died from a heavy blow to the head. Witnesses report that Principal Stern was seen at lunch time in the In and Out café having a heated discussion with the parents of two of Cowtown High's best basketball players. According to reports the boys had been expelled from school for smoking in the toilets.

Mrs. Stern said that her husband had gone to school early that morning as usual . " he eats lunch every day at the In and Out Café and then usually goes jogging in Tulip Park I always worry about him because he jogs along South Street, which always busy at that time.

Officer Smart and Detective Stumblebum are investigating this crime and would appreciate help from any of Cowtown's citizen who may have seen Principal Stern at any time yesterday.

(Taken from Oral, 2005) 


\section{3-Situations}

\section{Problem Solving Activities}

a) Auntie Agony Letters The students may work in groups to respond to the letters. They may produce multiple claims, encounter opposing arguments (solutions), and try to refute the arguments and reach a logical solution

\section{\begin{tabular}{|l|l} 
Dear Auntie Agony & Dear Agony Aunt,
\end{tabular}}

I'm experiencing terrible trouble from my sister I fear it's caused by hormones. She has been showing the following symptoms: she has had violent mood swings; she has even tried to kill me once or twice. Aunty Anne, what shall I do?
I've been getting more and more spots. I can't control them. I've used all the medicines but none of them work. I'm so ashamed of them. I look like a big fruit cake. Please help?

Paranoid Silvia

From Welist

\section{b) Troublesome Settings}

\section{Campbell Soap Game}

- The task of your team is to solve the following problem:

- Your group is a team of explorers sent from the planet Juno to the

- planet Earth in the year 2300 A.D. Your mission is twofold. You

- are to find out:

- 1. Whether or not Earth can support life.

- 2. Whether or not life exists or ever has existed on the planet.

- 3. If you feel that life has existed, how advanced it might have been.

- When you arrive on Earth, you find everything desolate. There are no cities,

- farms, or visible forms of life, either animal or plant. In fact, the only thing you find in your explorations is a box buried just beneath the land's surface. Inside the box are five cans of Campbell's soup.

- Based on your discovery, what would you report back to your superiors relative to the goals of your mission, and what evidence would you use to support the specifics of your report?

(Taken from Russel, 1996:2)

\section{c) Funny problems}

\section{- There are ten little ducklings in a pond.}

- First duckling tells she has nine little ducklings behind her

- Second duckling tells she has eight little ducklings behind her

- Third duckling tells she has seven little ducklings behind her

- Fourth duckling tells she has six little ducklings behind her.

- Fifth duckling tells she has five little ducklings behind her. 
- Sixth duckling tells she has four little ducklings behind her.

- Seventh duckling tells she has three little ducklings behind her.

- Eight duckling tells she has two little ducklings behind her

- Ninth duckling tells she has one little duckling behind her.

- Tenth duckling tells she has nine little ducklings behind her

- How could this happen?

- Probable Answer: The last duckling is a LIAR or they form a CIRCLE.

(Taken from Oral, 2005)

\section{Decision Making Activities}

\section{BEAN PLANTS}

The setting is a third grade classroom. It is May 15. In early March, each youngster planted a bean seed as part of a science project. Most seeds survived, and there are now eighteen healthy bean plants growing in the room. Since school will soon be ending, a decision must be made about what to do with the bean plants.

You are the teacher. Obviously, you could decide what to do with the plants. But, you could make this an opportunity for the class to exercise the decisionmaking thinking strategy.

(adapted from Russel, 1996:40)

4- Literary texts: All sorts of literary texts (short stories, novels, drama, poetry) may be of value to immerse students into thinking as literary texts are argumentative in nature. Literature offers students more opportunities than any other area of the curriculum to consider ideas, values, and ethical questions (Carr, 1990). Especially short stories because they more compact and condensed, are practical for classroom use. The elements like plot, characters, conflict, climax, and resolution can be recognized and made ready to have students produce claims, reasons, and evidence. Students have the opportunity to discuss and encounter opposing arguments they might refute or they can can come up with fallacies and reach a solution.

Stories Incomplete: Based on the evidence introduced, the students may produce claims/predictions, show evidence, reach a conclusion in order to complete the stories. 
An unknown substance oozed between his toes. It had a faint glow, when the eyes didn't focus on it.

Somehow he could evade them without being noticed. They seemed distracted and worried, but it was hard to figure out why because their mannerisms were so...well...alien.

The ooze was beginning to sting his feet and he thought to himself, "I had better get out of this stuff."

Above his head were tubes of varying length. They seemed to be sources of the ooze. He decided to try tugging on one to see if they might support his weight......................

Taken from Martin Studio-http://www.martin-studio.com/stories/show story.

5-Graphic Organizers:Graphic organizers are effective visual aids which show information structure of the texts and arrange essential aspects of an idea or topic into a pattern using labels Graphic organizers are excellent tools for learning the structure of thinking skills. A graphic organizer provides a powerful visual picture of information and allows the mind "to see" patterns and relationships (Galligan, 2004)

They can be used to enhance learning and create a foundation for learning. As each detail (facts, relationships, properties, conflict, storyline, characters as in the case of stories) can be easily visualized through the use of graphic organizers, they are worthy to promote thinking skills to a great extent (Grabe, 1997:2-15). Graphic organizers help the student recall the information in the text to be used for claims, arguments, evidence, reasons, and assumptions on which they will probably construct their reasoning and which give way to healthy reasoning, evaluations, and decisions.

Such graphics can be created by the teachers and then the responsibility can be given to students. They put thought into their learning rather than simply recall the facts.Their thought are incorporated in their learning, make meaningful connections improve their recall (Jiang and Grabe, 2007). The following graphic organizers can be given as examples:

1- Fishbone Chart to visualize cause and effect relationships

2- Lotus Chart to visualize the properties of an object/person or aspects of a topic.

3- Story Mapping Chart to visualize story grammar

4- Venn Diagram to compare and constrast two or three elements.

5- Web Diagram to explain the relationships (Collier, et al, 2002) 


\section{Conclusion}

Critical thinking enables the learners to determine their own criteria and to judge and question an idea or thought based on a reliable evidence and produce assertions. They need to produce assertions that is based on relevant, accurate facts; based on credible sources; precise; unbiased; free from logical fallacies; logically consistent; and strongly reasoned" (Beyer, 1995). Therefore, critical thinking is a necessity at all levels of education for a life long learning. It's much easier to teach students to memorize facts and then assess them with multiple-choice tests. When thinking critically is emphasized and taught, such a habit will probably be transported to their lives. They will be individuals who are aware of their own learning, as those who can question, judge and establish healthy reasoning based on reliable evidence and fight against the fallacies and finally draw robust conclusions when they are required to solve problems and make decisions.

With the statements of Occam's Razor, the ELT learners will be pushed into testing and validating the truth of a text or a speaker. They will understand that they should not believe everything they hear and read. Through the use of Scenarios, they will consider all sorts of evidence and reach a conclusion based on them. Problem Solving Activities (Auntie Letters, Troublesome Settings, Funny Problems) will encourage them to recognize the problem, devise a plan for solution and execute the plan. Decision Making Activities will offer many opportunities for the learners to define goals, find alternatives and select the best alternative. Literary texts in nature are unique in reflecting different perspectives, therefore they form a basis for argumentation in the classroom. Different interpretations will come into play and the thoughts will fight against one another in an attempt to find the best interpretation. Logical fallacies are identified. As for Graphic Organizers, they are used to visualize the characteristics of the texts and the information graphically that will construct reasoning. To summarize, in all activities where mechanical learning and rote-memorization are highly abandoned, thinking and speaking (preferably L2) are tightly woven.

\section{References}

Beyer, B. K. (1985)“Critical Thinking: What Is It?” Social Education 49/4: 270-276.

Beyer, B. K. (1995). Critical Thinking. Bloomington: Phi Delta Kappa Educational Foundation.

Carr, Kathryn S. (1990) How Can We Teach Critical Thinking? ERIC Digest. ERIC Clearinghouse on Elementary and Early Childhood Education Urbana IL. ERIC Identifier: ED326304 
Chance, P. (1986). Thinking in the classroom: A survey of programs. New York: Teachers College,

Columbia University.

Collier, K, Guenther, T., Veerman, C. (2002). Developing Critical Thinking Skills Through a Variety of Instructional Strategies. An Action Research Project submitted to the Graduate Faculty of the School of Education as a Requirement of the Degree of Masters of Arts in Teaching and Leadership. Saint-Xavier University. Chicago, Illinois.

Galligan G. (2004) Graphic Organizers. http://www.kn.sbc.com/wired/fil/pages/listgraphicga.html

Grabe, B. (1997). Discourse Analysis and Reading Instruction. In Functional Approaches to Written Text: Classroom Applications (2-15) English Language Programs United States Information Agency.

Jiang, X and GrabeW (2007) Graphic Organizers In Reading Instruction: Research Findings And Issues Reading in a Foreign Language. Volume 19, Number 1.

Knott, D. (2005) Critical Reading Towards Critical Writing http://www.utoronto.ca/writing/critrdg.html

Kurland, D.J. (2000). Critical Reading. http://www.criticalreading.com/critical_reading.htm

http://www.crescentlife.com/articles/education/critical thinking.htm

Russell L. (1996) Lousiana Teacher Assistance and Assessment Program.University of Tennessee, Knoxville.

Martin Studio. Stories. Retrieved on June 10, 2007

http://www.martin-studio.com/stories/show_story.do?rec=70

Oral, M. (2005). Thinking Outside the Box: An Introduction to Critical Thinking . Saturday Teacher Training Workshops. Turkish-American Association Ankara.

Paul, R., (1990) Critical Thinking: What Every Person Needs to Survive in a Rapidly Changing World. Rohnert Park, CA: Center for Critical Thinking and Moral Critique

Stapleton, P. (2001). Assessing Critical Thinking in the Writing of Japanese University Students. Written Communication Vol.18 No. 4 October 506-548 Sage Publications.

Taylor, Chris. (2001) 'It's the real thing' Using Ads To Promote Critical Thinking In the EFL Classrooms. News In Brief. The Quarterly Newsletter of INGED. Pp.1012

Uzma, Mazhar (2003). Critical Thinking. Retrieved January 31, 2005

Uzma, Mazhar (2005).http://www.crescentlife.com/articles/education/critical_thinking.htm

Wickipedia (2005) Free Online Encylopedia http://en.wikipedia.org/ 


\section{Appendix I \\ A SOCRATIC QUESTIONING}

Clarification Questions:

- What do you mean by

- What is your main point?

- How does relate to

- Could you put that another way?

- What do you think is the main issue here?

- Let me see if I understand you; do you mean or ?

- Jane, would you summarize in your own words what Richard has said?...Richard, is that what you meant?

- Could you give me an example?

- Would this be an example:

- Could you explain that further?

- Could you expand upon that?

Questions About the Initial Question or Issue:

- How can we find out?

- What does this question assume?

- Would __ put the question differently?

- How could someone settle this question?

- Can we break this question down at all?

- Is the question clear? Do we understand it?

- Is this question easy or hard to answer? Why?

- Does this question ask us to evaluate something?

- Do we all agree that this is the question?

- To answer this question, what questions would we have to answer first?

- I'm not sure I understand how your are interpreting the main question at issue.

- Is this the same issue as

- How would _ put this issue?

- Why is this question important?

- Does this question lead to other questions or issues?

Assumption Probes:

- What are you assuming?

- What is Karen assuming?

- What could we assume instead?

- You seem to be assuming Do I understand you correctly?

- All of your reasoning depends on the idea that. Why have you based your reasoning on rather than
- You seem to be assuming ___. How would you justify taking this for granted?

- Is it always the case? Why do you think the assumption holds here?

- Why would someone make this assumption?

Reason and Evidence Probes:

- What would be an example?

- How do you know?

- Why do you think that is true?

- Do you have any evidence for that?

- What difference does that make?

- What are your reasons for saying that?

- What other information do we need?

- Could you explain your reasons to us?

- Are these reasons adequate?

- Can you explain how you logically got from to---?

- Do you see any difficulties with their reasoning here?

- Why did you say that?

- What led you to that belief?

- How does that apply to this case?

- What would change your mind?

- But is that good evidence to believe that?

- Is there reason to doubt that evidence?

- Who is in a position to know if that is so?

- What would you say to someone who said ?

- Can someone else give evidence to support that response?

- By what reasoning did you come to that conclusion?

- How could we find out whether that is true?

Origin or Source Questions:

- Where did you get this idea?

- Do your friends or family feel the same way?

- Have you been influenced by media?

- Have you always felt this way?

- What caused you to feel this way?

- Did you originate this idea or get it from someone else?

Implication and Consequence Probes:

- What are you implying by that? 
- When you say are you implying ?

- But if that happened, what else would happen as a result? Why?

- What effect would that have?

- Would that necessarily happen or only probably happen?

- What is the probability of this result?

- What is an alternative?

- If this and this are the case, then what else must also be true?

- If we say that this is unethical, how about that?

Viewpoint Questions: You seem to be approaching this issue from perspective. Why have you chosen this rather than that perspective?

- How would other groups/types of people respond? Why? What would influence them?

- How could you answer the objection that would make?

- What might someone who believed think?

- Can/did anyone see this another way?

- What would someone who disagrees say?

- What is an alternative?

- How are Ken's and Roxanne's ideas alike? Different?

http://okra.deltastate.edu/ bhayes/socratic.h $\underline{\mathrm{tml}}$ 